\title{
Withholding and withdrawing life-sustaining treatment: The Canadian Critical Care Society position paper
}

\author{
On Behalf of the Canadian Critical Care Society Ethics Committee $\cdot$ Natalie Bandrauk, MDCM, MSc, FRCPC • \\ James Downar, MDCM, MHSc, FRCPC • Bojan Paunovic, MD, FRCPC
}

Received: 14 September 2017/ Accepted: 17 October 2017/Published online: 17 November 2017

(c) Canadian Anesthesiologists' Society 2017

\section{Section 1}

\subsection{Purpose}

This document serves as a guide and an educational tool for all members of intensive care unit (ICU) multidisciplinary teams and those involved in end-of-life (EOL) decisionmaking. It aims to improve the understanding of ICU EOL issues and to provide guidance to facilitate the process of selecting a course of action. Accordingly, this document can be adopted, or adapted, for local use in accordance with legislation, provincial College statements/guidelines, or institutional requirements/policies.

\subsection{Definitions (as applied in this document)}

\subsubsection{Life-sustaining treatments}

Life-sustaining treatments (LSTs) are medications or medical devices (also known as life support) using mechanical or other artificial means to support or replace vital organ function on either a temporary or permanent basis. Life-sustaining treatments are distinct from therapy

N. Bandrauk, MDCM, MSc, FRCPC

Faculty of Medicine, Memorial University, St-John's, NL, Canada

J. Downar, MDCM, MHSc, FRCPC

Divisions of Critical Care Medicine and Palliative Care, Department of Medicine, University of Toronto, Toronto, ON, Canada

B. Paunovic, MD, FRCPC ( $\square)$

Section of Critical Care Medicine, Max Rady College of Medicine, University of Manitoba, Winnipeg, MB, Canada e-mail: bpaunovic@hsc.mb.ca in that LSTs merely sustain rather than restore organ function. Moreover, LSTs are not routine medical interventions; rather, they are specialized measures that require specialized medical staff, specialized locations, and significant resources. Accordingly, ongoing use of LSTs necessitates admission to a specialized area such as an ICU within an acute care hospital. Life-sustaining treatments can include mechanical ventilation, pharmacological or mechanical hemodynamic support, and hemodialysis.

\subsubsection{Cardiopulmonary resuscitation}

Cardiopulmonary resuscitation (CPR) is an intervention applied following cardiac or respiratory arrest with the potential to prevent premature death or to prolong inevitable death. Cardiopulmonary resuscitation may include chest compressions, bag and mask positivepressure ventilation, intubation, and/or defibrillation. Despite originally being intended for select cases, it is now applied in many cases of sudden death unless a contrary order- e.g., "No CPR" or "Do not attempt resuscitation" (DNAR), has been recorded in the health record. Cardiopulmonary resuscitation is not clinically indicated in all cases and therefore should not be considered a default intervention. ${ }^{1}$ Furthermore, CPR is not an all-or-none intervention. Certain components of CPR (e.g., intubation) may be clinically appropriate, whereas others (e.g., chest compressions, defibrillation) may not.

\subsubsection{Withholding and withdrawing life-sustaining treatment}

Withholding and withdrawing life-sustaining treatment (WWLST) are processes by which medical interventions 
are forgone or discontinued, often with the understanding that the patient will most probably experience natural death from the underlying disease or related complications. Withholding and withdrawing life-sustaining treatment is not equivalent to medically assisted death or euthanasia, as outlined in Section 2.5.

Competence, in the context of medical consent, refers to a patient's capacity to understand the information presented and to appreciate the reasonably foreseeable consequences (including the potential risks and benefits) of a decision or lack thereof. A competent patient or their substitute decision-maker can provide or refuse informed consent for a treatment plan when s/he reasonably understands the diagnosis, risks, benefits, and clinically indicated alternatives.

Substitute decision-maker (SDM) is also referred to as a proxy or representative. When a patient is no longer competent to make healthcare decisions, an appropriate SDM should be identified and afforded the same opportunity for a thorough discussion of the patient's care plan. This representative should be chosen based on a willingness and ability to make decisions that reflect the patient's most recent wishes, if explicitly stated, or their likely wishes, if not expressed. In some instances, an SDM may have already been legally declared. It is important to refer to local legislation to ensure the appropriate process. ${ }^{2}$

Standard of care follows the ruling in Crits v. Sylvester (1956) S.C.R. 991. This held that a physician is "...bound to exercise that degree of care and skill which could reasonably be expected of a prudent practitioner of the same experience and standing..." This means that a physician would be expected to propose or provide a treatment that most physicians with similar training and experience would propose or provide in a similar situation. Conversely, it means that a physician would not be expected to propose or provide a treatment that most physicians with similar training and experience would not propose or provide in this individual situation.

\subsection{Ethical principles}

Four basic ethical principles ${ }^{3}$ outlined below are related to and complement one another. These principles are intended to frame discussions but do not mandate what healthcare providers (HCPs) "should" or "must" do, either individually or collectively. Not infrequently, there may be variance between these principles - typically between respect for autonomy and the principle of beneficence, between beneficence and non-maleficence, and between respect for autonomy and justice. No single principle supersedes others, and broader familiarity with these elements is meant to assist in the management or resolution of dilemmas and conflicts.
Beneficence refers to actions that are intended to benefit patients by treating illness, promoting health, and/or relieving pain, suffering, and distress.

Non-maleficence, the principle of "primum non nocere" or "first do no harm", requires that HCPs strive to minimize patient suffering, harm, or distress. A proposed treatment may involve unavoidable harm, suffering, and distress, in which case, it must be justified by a reasonable expectation of patient benefit.

Respect for autonomy asserts the right of competent patients/SDMs to accept or refuse medical treatments. This includes the right to accept or refuse LSTs. Consent requires reasonable explanation of the nature and implications of proposed interventions and provides an understanding of the consequences of any decisions to accept or forgo these interventions. Competent patients may preserve their autonomy in future states of incapacity by declaring their goals, wishes, and treatment preferences or by designating an SDM to represent those values following incapacity (see Section 2.4).

Justice is the principle by which all patients should have equitable access to healthcare. This includes LST, unless that treatment has no reasonable expectation of an outcome acceptable to the patient or is determined to be merely delaying inevitable death. In extraordinary situations, such as a pandemic or disaster triage, medical resources (consistent with standards of medical practice) should be allocated to maximize the chance of success.

\section{Section 2}

\subsection{The distinction between withholding and withdrawing life-sustaining treatment in Canada}

Western biomedical ethics does not distinguish between withholding life-sustaining treatment (WHLST) and withdrawing life-sustaining treatment (WDLST). In some countries, WHLST may be permitted, but WDLST is considered unethical or illegal regardless of consent. In Canada, neither WHLST nor WDLST is considered the cause of death as it is the underlying disease process that is responsible for the death. Nevertheless, there can be a psychological difference between WHLST and WDLST. Many patients, family members, and some HCPs are uncomfortable with the moral agency involved in withdrawing LST (an active act of commission) and more accepting of withholding LST (a passive act of omission).

It is important not to overstate the moral or legal distinction between WHLST and WDLST, as there may be no clinically meaningful distinction between withdrawing a treatment and withholding the next dose or escalation. Withdrawal of treatment can usually be reframed as 
withholding treatment and vice versa. For example, discontinuing intermittent hemodialysis could be considered a withdrawal of hemodialysis or a withholding of further dialysis. A DNAR order would withhold future CPR. Alternatively, it could be framed as a withdrawal of a previous care plan that had included CPR in the event of an arrest.

Second, any form of LST should be considered a trial that should continue as long as it is desired by the patient and involves a reasonable prospect of recovery to a meaningful patient-centred quality of life. If the patient withdraws consent at any point, or if the healthcare team assesses that there is no realistic prospect of a meaningful recovery, the trial should then be discontinued or modified.

In practical clinical terms, approaching WDLST differently from WHLST could adversely affect patients. It could prevent appropriately discontinuing resuscitation once it is clear that it has not restored life, and LST could become open-ended despite patient suffering or lack of meaningful benefit. Moreover, if WDLST and WHLST are deemed morally distinct and separate, then patients, families, or physicians may hesitate to initiate a trial of LST in indeterminate cases. In other words, when there is a reasonable but not absolute likelihood of a poor outcome, there may be reluctance to start a trial if there is no subsequent option to stop.

In short, it is central to medical practice that all medical interventions, not just LSTs, are individualized to patient benefit, routinely reassessed, and open to discontinuation. This approach minimizes inappropriate suffering and distress for patients and caregivers, burnout in HCPs, and inappropriate use of finite resources.

In Ontario, the Supreme Court of Canada has reviewed the legality of the equivalence of WDLST and WHLST. ${ }^{4}$ The Court held that consent is required for WDLST for a patient who would be expected to die imminently without that LST. Nevertheless, the 5-2 split ruling is problematic:

i) It did not explicitly state whether WDLST and WHLST are equivalent.

ii) The court referred to provincial legislation for resolving the disagreement between HCPs and family/SDM regarding WDLST. Not every province/ territory has relevant legislation to follow.

iii) It specified that the need for consent for WDLST is specific to the Rasouli case (namely, the discontinuation of mechanical ventilation in a severely brain-injured patient), and also that not all forms of treatment withdrawal may require consent. Nevertheless, the decision did not further delineate when consent is required for other forms of WDLST.

Moreover, cases in other provinces have not clarified the role of consent in WWLST. As such, the legality in Canada regarding decision-making in WHLST remains undetermined and only narrowly defined with regard to WDLST in the province of Ontario. ${ }^{5}$

2.2 Withholding and withdrawing life-sustaining treatment: decision-making considerations

(i) Using best clinical judgement, members of the healthcare team should determine whether LST has a reasonable chance of restoring the patient to a quality of life that s/he would find meaningful. When it is clear that treatment will not be medically effective and is not in accordance with the standard of care, the physician is not obliged to begin, continue, or maintain the treatment. (1)

(ii) Life-sustaining treatment is not an all-or-none treatment plan. As such, an order to withhold CPR (or DNAR) should not necessarily exclude patients from receiving other appropriate LST or admission to the ICU. Likewise, patients who refuse or are not offered LST may still receive aggressive medical care, which can include treatments (e.g., antibiotics, procedures, radiological tests, laboratory work), comprehensive efforts at rehabilitation (feeding and hydration, physiotherapy), and full attention from HCPs (analgesia, spiritual care, regular patient and family updates). A limit on LST should not be interpreted or represented as resulting in patient neglect.

(iii) If it is not clear whether individual patients could recover to a meaningful quality of life, a trial of LST could be offered but regularly reviewed for appropriateness. The ICU team should communicate clearly and consistently with patient and SDM/family members about the goals and objectives of LST. It is possible for LST to be appropriate at the outset but become inappropriate due to changes in the patient's condition. If this occurs, the ICU team should propose withdrawing LST and prioritizing palliation.

(iv) There should be consensus among ICU team members about the options (including palliation) and the recommended plan before anyone approaches the patient/SDM regarding WWLST. In some circumstances, it may be advisable to seek at least one additional ICU physician's opinion to ensure that all reasonable options have been explored and that WWLST is consistent with the standard of care. The team may also seek additional consultation of other relevant clinicians or ethicists to determine whether it is appropriate to provide/continue LST. 
(v) It is important that HCPs maintain consistent communication with the patient/SDM. There should be structures in place to facilitate comprehensive and regular sign over between HCPs.

(vi) When assessing whether a particular medical problem is likely reversible/recoverable, the appropriateness/desirability for initiation or continuation of LST should be interpreted in the context of the patient's overall prognosis, values, and longer-term goals.

(vii) When planning discussions of WWLST, other members of the healthcare team should be involved. It may also be appropriate, if the patient/ SDM or family agrees, to seek the additional presence of an appropriate spiritual health provider and/or social worker. Importantly, it should be clarified which family members/ friends are to be present during discussions.

(viii) Good communication is central to decision-making. Where possible, the patient, SDM, and family should all participate in the decision-making process, as each will have to deal with the consequences and potential distress arising from the decision. Good communication between the ICU team, patient/SDM, and family can enhance mutual trust and support and reduce the possibility of disagreement or confusion. Therefore, both clinicians and SDMs should commit to keeping the lines of communication open.

(ix) Every effort should be made for patients to be involved in discussions about their own medical decisions and treatment. Nevertheless, the nature of cardiopulmonary collapse means that many patients will be comatose, non-communicative, or only partially communicative. When able to communicate directly with patients, it may be appropriate to disclose information judiciously to avoid imposing a severe emotional burden on a person who may already be distressed. This may involve asking the patient how much they wish to know or providing limited information initially while awaiting a more appropriate setting, additional support, and readiness of the patient to receive information. In so doing, trust can remain intact and enable subsequent discussions where full disclosure can take place.

(x) Some patients may not wish to know their medical condition or to be involved in treatment decisions. The ICU team may want to recommend that the patient be involved in their own treatment decisions, but ultimately, they should respect a patient's clear decision not to be involved. A physician who overrides this preference is not respecting patient autonomy. Physicians could determine this in a nonthreatening and non-judgemental manner by asking the following: "When I talk with patients, some want to know all about their condition and the treatment options. Others prefer not to know and want me to make treatment decisions with their family. I am agreeable to either approach, but I would like to know which you prefer."

(xi) It is important to recognize the influences of nonmedical factors in discussions concerning WWLST. Patients may have cultural/religious/spiritual beliefs that have shaped their attitudes to life, illness, and death and will influence their feelings about WWLST. Individual views of the ICU team members must not interfere with the provision of unbiased and non-judgemental care. Multiple faiths and beliefs are practiced in Canada, and HCPs frequently deal with patients whose faith and beliefs differ from their own. Spiritual health services should be considered a resource for exploring and valuing these perspectives.

(xii) Since families, SDMs, and members of the healthcare team may need time to come to terms with the impending death of a patient/loved one, any recommendation to withdraw or limit ICU care should be discussed respectfully and compassionately. Healthcare providers may seek the advice of the ethics consultation service, the spiritual health service, social work, and/or other available resources. In addition, the following considerations apply:

- Beneficence and compassion require that the decision-making process be unhurried when possible. Since patients/SDMs and family members may need time to come to terms with the proposed WWLST, this process may require more than one meeting.

- Discussions should be calm, honest, respectful, and compassionate. Medical jargon should be avoided so that everyone can understand the terms being used.

- Family/SDM may recognize that agreeing with the medical plan offered is in the best interest of the patient but - for various personal, psychological, cultural reasons - do not want the burden of decision-making and cannot explicitly provide consent (or "give permission"). It is important that the ICU team recognize those situations where implicit consent is preferred.

- Patients/SDMs and family members may perceive WWLST as a form of abandonment. Every effort should be made to provide support 
and to emphasize that care, including symptom management, will be continued to minimize patient distress. Where appropriate, it should be emphasized when WWLST is beneficial, as it allows a full focus on patient comfort that may not be possible otherwise.

(xiii) Documentation should occur that includes names of those present, the content of the discussion, and the plan and timeline related to WWLST. In discussions that raise significant concern, it is advisable that senior physicians co-sign or document the encounter themselves.

(xiv) When the above considerations are applied, there is less likely to be disagreement over WWLST between the ICU team and patient or SDM. Nevertheless, when disagreement arises, it is usually in two distinct situations:

1) a discussion about a patient who is deteriorating and expected to die imminently, and 2) a preemptive discussion for a patient without imminent expectation of deterioration.

In the first situation, if a significant escalation of care (e.g., the provision of chest compressions in the setting of a deteriorating condition despite ongoing LST) is considered outside the standard of care, then patients/SDMs should be informed that it will not be provided. In the event of that deterioration, it should also be clarified that the patient will not be neglected, ignored, or abandoned and will receive full care to minimize discomfort and treat/prevent suffering as required. These efforts are not intended to hasten the dying process; rather, they are meant to focus on maximizing patient benefit and minimizing harm (see 3.2 for further discussion).

In the second situation, it is prudent not to rush decisions and to emphasize that the decision affects only the care that the patient would receive if s/he were to deteriorate despite all reasonable therapeutic efforts. The goal is to explore the situation preemptively, to allow time to discuss and revisit, and to maximize the likelihood of the patient communicating his or her own wishes. The goal is to minimize subsequent communication gaps and to achieve consensus without the added difficulty of decision-making under time pressure. The plan should reflect the patient's best interests and should be respected by the SDM/family and the healthcare team.

In either case, the ICU physician should consider using all available resources to inform the decision. This may include confirming consensus among other members of the healthcare team and considering additional opinions from colleagues, either in person or remotely.

Institutions/health regions should establish a reporting process among the healthcare team that regularly reviews these issues in real time and retrospectively. Disputes in goals of care should be addressed with additional physician opinions, especially for the stable patient when there is not significant time pressure. This increases transparency and adherence to practice standards. It also eliminates the perception of unilateral decision-making.

Healthcare providers should also be familiar with their local conflict resolution processes (see 3.4).

(xv) It is important to be cognizant of local differences and follow applicable provincial College policies and provincial legislation (where available) as they relate to WWLST. ${ }^{6-9}$

(xvi) Decisions regarding LST are to be reviewed if there is a significant/unexpected change in the patient's condition that might alter the previously stated prognosis on which the previous care plan was based.

2.3 Withholding and withdrawing life-sustaining treatment at the request of a competent patient

(i) A competent patient has the right to forgo or request withdrawal of all forms of medical intervention, including LST. Decisions should be informed, voluntary, and without coercion and made preferably when the patient's competency and ability to communicate are not compromised. Complying with a patient's wishes to forgo offered intervention is distinct from physician-assisted death (see Section 2.5).

(ii) When an SDM/family member expresses opposing wishes/views to those expressed by a competent patient, these views should be noted and discussed, but they do not override the choices expressed by the patient. If the patient subsequently loses capacity, the $\mathrm{SDM}$ /family member may not substitute his/her own wishes for the patient's known wishes.

(iii) If a competent patient changes his/her mind regarding their expressed wishes, the latest expressed wishes prevail in the context of offered treatment, whether or not they confirm or contradict earlier decisions.

\subsection{Withholding and withdrawing life-sustaining treatment using substituted decision-making}

Advanced care planning is a process of preemptive discussion and communication for patients to establish their goals, values, and preferences for care. It involves naming an SDM and often written documentation. This documentation can take the form of directives, living wills, 
or care plans. Further elaboration of this process is not the intent of this position paper but the following provides guidance:

\subsubsection{Directives}

(i) A directive is a document executed by a competent individual concerning healthcare decisions to be made in the event that the individual becomes incompetent to make such decisions. The purpose of the directive is to maintain the autonomy of the patient even when s/ he loses decisional capacity. It is directed to the SDM/family and the healthcare team. A copy of the directive should accompany the patient when s/he is admitted to a healthcare facility.

A directive usually specifies an individual SDM whom the patient has chosen to make healthcare decisions in the event that s/he loses decisional capacity. It may also specify the patient's values or instructions that should be used to guide healthcare decisions or indicate specific treatments that the patient would or would not want to receive. A directive cannot compel the healthcare team to provide treatments that lie outside the standard of care, and it cannot direct a proxy to do so. Categorical statements (e.g., "I would never want to receive...", or "I want CPR no matter what happens...") should be given consideration but should not be taken as literal instructions when made in the absence of clinical context.

Many different types of directives, e.g., generic, disease specific, and institutional, are in use across Canada. Provincial legislation and institutional policies also vary, and HCPs must be familiar with their local requirements. ${ }^{2}$

(ii) When there is no written directive, a competent and informed patient can verbally communicate their wishes and preferences, and these verbal directives should guide care in the same way as written instructions. Nevertheless, this conversation should be documented in accordance with institutional policy such that it may inform future healthcare encounters.

In general, statements made by an acutely incapable patient (in relation to acute illness or medication and therefore likely reversible) do not supersede the patient's own prior statements/directives when they were competent. Nevertheless, when discrepancies occur, physicians must consider the clinical context and the patient's presumed best interests. New information that was not available to the patient when setting their directive may influence and warrant a review of current and future goals.

\subsubsection{Absence of directive}

(i) In emergency situations, such as cardiac arrest, medical decisions may need to be made prior to knowledge or review of a directive. In this situation, HCPs and SDMs should follow what they consider to be in the patient's best interests.

(ii) When possible, an SDM should be identified in accordance with the appropriate provincial legislation and institutional policy, and this person should participate in the decision-making process on the patient's behalf.

(iii) The identified SDM is the recognized source of consent to treatment plans. The role of the SDM is to reproduce the choices the patient would make if $\mathrm{s} / \mathrm{he}$ still had capacity. In this undertaking, the patient's own concept of wellbeing is respected, as is his/her interest in self-determination. In the absence of clear and relevant directives, the SDM should apply the "best interests" standard. This standard involves considering the patient's overall wellbeing, their general values and beliefs, and the potential burdens and benefits of the treatment options.

(iv) If there is concern that the SDM is not acting in the best interest of the patient, the ICU team should then explore the rationale behind the SDM's decisions. It may be necessary to involve local resources, including patient relations, the ethics consultation service, or legal counsel, to clarify the role of the SDM and the best interests of the patient. In some jurisdictions, the ICU team can pursue legal means or a tribunal, such as the Consent and Capacity Board (in Ontario and the Yukon), for guidance or to allow the team to refer to a different SDM.

2.5 A respectful and dignified death

(i) If decisions are made to withhold or withdraw LST, the goals of patient care in the ICU focus on comfort and relief of suffering. The ICU team should provide a respectful, caring, and peaceful environment to ensure a dignified death and a reverent family experience.

(ii) Palliative care consultation services can provide additional expertise and support, and their use has been associated with a longer survival for patients. ${ }^{10}$ As such, palliative care should be considered in the transition to comfort care.

(iii) It must be recognized that not all patients have an imminent death when LST is withheld or withdrawn. In fact, some may survive to be transferred out of the ICU. Healthcare providers should prepare the family 
for this possibility and ensure that the patient's remaining time is as comfortable as possible.

(iv) Beneficence and compassion require the ICU team to support and facilitate the preparations of the patient and family for the impending death of the patient. This may include reasonable consideration for limited prolonging of life-sustaining efforts until completion of social and spiritual goals.

(v) When withholding or withdrawing LST, the ICU team may use opiates and/or other sedatives to relieve suffering. Although sedatives and opioids do not routinely hasten death when titrated to achieve comfort, it is possible that these medications may inadvertently hasten patient death. The doctrine of double effect holds that it is acceptable for comfort medications to potentially hasten death as long as that is not the intended effect of giving those medications. ${ }^{11}$ This is distinct from euthanasia and assisted suicide in which medications are given for the deliberate purpose of hastening death.

Although medical assistance in dying (MAID) has been decriminalized in Canada in specific circumstances, ${ }^{12}$ this is distinct from WWLST. Some patients/SDMs and family members may consider the withdrawal of LST to be equivalent to euthanasia and object to it accordingly. The ICU team should explain the difference. In WWLST, the intent of the ICU team is to allow the patient to die naturally from the underlying disease or its complications and to provide comfort as required. In contrast, in medically assisted death, the intent is to provide comfort by deliberately and actively ending the patient's life. Furthermore, it is also important to note that the specific conditions and processes required for MAID, while possible, are rare in the ICU setting.

\section{Section 3}

\subsection{Multicultural considerations}

Patients, SDMs, and HCPs reflect Canada's multicultural, multifaith, and multiethnic makeup. Due to the diversity both within and between the various faiths practiced in Canada, ICU team members may find themselves in circumstances where the beliefs held by their patients/families are not aligned with proposed changes to LST. The ICU team should be sensitive to the differing attitudes to WWLST. Furthermore, there can be discrepancies between personal practices and the common interpretations of the religious teachings which require further discussion. Thus, there is a need to be conversant with the beliefs of patients and families when there is any consideration of WWLST. In these circumstances, early involvement of the relevant spiritual health service is recommended. Section 2 of the Canadian Charter of Rights and Freedoms protects Canadians in following the religion of their choice and in not being discriminated against on the basis of that choice. Nevertheless, this should not be extrapolated to protecting demands that are inconsistent with medical or secular standards.

\subsection{Cardiopulmonary resuscitation (CPR) and do not attempt resuscitation (DNAR) orders}

The most common decisions regarding WWLST involve restricting or limiting CPR. It is important to note that disagreements between the healthcare team and patient/ SDM/family regarding CPR usually relate to misinformation/misunderstanding regarding the term "resuscitation". Moreover, disagreement usually stems from the concern that a NO CPR or DNAR order results in neglect or very limited attention to otherwise treatable conditions unrelated to a cardiac arrest. Proper explanation regarding the appropriateness of a DNAR order is required and should be accompanied by specifically addressing which, if any, LST will still be provided. It must be recognized and addressed that many members of the public (and some HCPs) are not fully informed about CPR or its sequelae. ${ }^{13}$ Cardiopulmonary resuscitation is distinct from standard ICU interventions such as elective intubation and mechanical ventilation, hemodynamic support, or vascular access procedures. Moreover, HCPs should explain that the likelihood of restoration of cerebral or corporeal health following CPR is variable but often poor, especially for frail patients, those who have failed to improve despite lengthy hospitalization, and those with advanced medical illness. ${ }^{14,15}$

There is no legal precedent in Canada for requiring the provision of CPR in situations where a physician determines that this lies outside the standard of care. The CCCS asserts the principle that CPR should not be provided outside the standard of care, such as in the scenario outlined in 2.2 (xiv). For this reason, the CCCS disagrees with this aspect of the College of Physicians and Surgeons of Ontario policy on Planning for and Providing Quality End-of-Life Care. The College of Physicians and Surgeons of Manitoba statement on WWLST also discusses the provision of CPR. Practitioners in these provinces must familiarize themselves with these policies. Ultimately, the duration and interventions performed during CPR should be consistent with the standard of care and clinical judgement, taking into account whether this aggressive intervention offers an opportunity to reverse premature death vs prolong an inevitable death or 
unnecessary patient suffering. When provided, there is no minimum duration for performing CPR, and there are no mandatory interventions required during every episode of CPR. ${ }^{16,17}$

\subsection{Resources}

When ICU demands exceed local resources, the ICU team is on the forefront of crisis management. This potentially places the treating team in the role of resource allocation. A perceived lack of resources should at no time-other than where pandemic or natural disaster legislation deems otherwise-solely influence a decision to withhold or withdraw LST regarding an individual patient. Preemptive healthcare policy and local mechanisms at various levels (individual ICU, hospital, regional, provincial) should address delivery of ICU care when required. The ICU community is responsible for informing stakeholders of the requirements/resources needed to deliver adequate, appropriate, and timely ICU care.

\subsection{Impasse}

In clinical situations, there are at least two autonomous agents: the patient/SDM and the healthcare provider(s), each with their own responsibilities, values, and belief systems. Mutual respect for the autonomy of each agent is important. Nevertheless, when the healthcare team determines that specific intervention(s) are without medical benefit and/or fall outside accepted standards of practice, respect for patient autonomy should not oblige the team to acquiesce to the request of the patient/SDM for that intervention. ${ }^{1}$

Other critical care societies have addressed these issues and provide additional reflection and guidance. ${ }^{18,19}$

The healthcare team should communicate these decisions at the earliest opportunity and give patients/ SDMs the opportunity to disagree or request alternate opinion(s). The team should make good faith attempts to communicate and reach an agreement with the patient/ SDM about the plan of care. Nevertheless, there are still situations where no consensus can be achieved despite appropriate communication and repeated medical assessment. When this occurs, further attempts at resolution should be pursued if there is not a significant time pressure. Efforts should include:

(i) Another effort at extended discussion with patient, family, other healthcare providers, and spiritual care providers (as outlined in Section 2.2);

(ii) Meeting of all parties with a mediator or impartial third party such as an institutional ethics consultant or equivalent; (iii) A formal conflict resolution process (in institutions/ regions) that includes multiple representatives and stakeholders and can be implemented when decisionmaking is required for both urgent and more protracted situations (Canadian Medical Association Joint Statement on Preventing and Resolving Ethical Conflicts 1999) ${ }^{20}$;

(iv) Consideration regarding transfer of the patient to an alternative physician or institution, which, if not achievable, should be clearly explained to the patient/SDM/family; and

(v) Adjudication by the Consent and Capacity Board, where available, or by the courts. This should be available to all stakeholders; however, it should be recognized that these processes are not time sensitive and are resource intensive. ${ }^{20}$

\section{Conclusion}

Discussions regarding WWLST must be collaborative and transparent. They should be centred on patient wishes that are informed and contextual and on medical decisions that are supported by standards-based consensus. When LST is no longer beneficial or wanted, an empathetic and supportive approach with patients and families will ensure that communications are shared in the best possible light despite the difficulty of the situation.

\section{L'abstention et l'interruption des traitements de maintien de la vie : exposé de principe de la Société canadienne de soins intensifs}

\section{Section 1}

\subsection{Objectif}

Ce document sert de guide et d'outil de formation destiné à tous les membres d'équipes multidisciplinaires dans les unités de soins intensifs (USI) et aux personnes participant à la prise de décision concernant la fin de vie. Son objectif est d'améliorer la compréhension des questions qui touchent la fin de vie à l'USI et d'offrir des pistes afin de 
faciliter le processus de sélection d'un plan de prise en charge. C'est pourquoi ce document peut être adopté ou adapté pour une utilisation locale tout en respectant les lois, les énoncés et lignes directrices des Ordres provinciaux, ainsi que les exigences et politiques institutionnelles.

\subsection{Définitions (telles qu'elles s'appliquent dans ce document)}

\subsubsection{Traitements de maintien de la vie}

Les traitements de maintien de la vie sont des médicaments ou des dispositifs médicaux (aussi connus sous le nom de soutien des fonctions vitales) qui utilisent des moyens mécaniques ou artificiels pour soutenir ou remplacer le fonctionnement des organes vitaux de façon temporaire ou permanente. Les traitements de maintien de la vie se distinguent de la thérapie en ce qu'ils ne font que soutenir le fonctionnement des organes et non le restaurer. En outre, les traitements de maintien de la vie ne sont pas des interventions médicales de routine; il s'agit plutôt de mesures spéciales qui nécessitent un personnel médical spécialisé, des lieux dédiés et des ressources considérables. C'est pourquoi l'utilisation ininterrompue de traitements de maintien de la vie nécessite l'admission à une unité spécialisée telle qu'une USI au sein d'un hôpital de soins aigus. Les traitements de maintien de la vie peuvent comporter la ventilation mécanique, le soutien pharmacologique ou mécanique de l'hémodynamie, et l'hémodialyse.

\subsubsection{La réanimation cardiorespiratoire}

La réanimation cardiorespiratoire (RCR) est une intervention réalisée suite à un arrêt cardiaque ou respiratoire; cette modalité a le potentiel de prévenir une mort prématurée ou de prolonger le délai jusqu'à une mort inévitable. La réanimation cardiorespiratoire peut comprendre des compressions thoraciques, une ventilation au masque en pression positive, l'intubation et/ou la défibrillation. À l'origine, cette manœuvre n'était destinée qu'à certains cas particuliers; toutefois, on l'applique aujourd'hui dans de nombreux cas de mort subite, sauf ordonnance contraire - par exemple, une ordonnance «pas de RCR » ou «ne pas réanimer»documentée dans le dossier de santé du patient. La réanimation cardiorespiratoire n'est pas cliniquement indiquée dans tous les cas, c'est pourquoi elle ne devrait pas être considérée comme une intervention par défaut. ${ }^{1}$ En outre, la RCR n'est pas une intervention « tout ou rien ». Certaines composantes de la RCR (par ex., l'intubation) pourraient être appropriées d'un point de vue clinique, alors que d'autres (par ex. les compressions thoraciques, la défibrillation) pourraient ne pas l'être.

\subsubsection{L'abstention et l'interruption de traitements de maintien de la vie}

L'abstention et l'interruption de traitements de maintien de la vie sont des processus par lesquels on renonce aux ou on interrompt les interventions médicales, étant souvent entendu que le patient décèdera très probablement en raison de la maladie sous-jacente ou de ses complications associées. L'abstention et l'interruption de traitements de maintien de la vie ne sont pas équivalentes à l'aide médicale à mourir ou à l'euthanasie, telles que décrites dans la Section 2.5.

La compétence, dans le contexte du consentement médical, fait référence à la capacité d'un patient à comprendre les informations présentées et à reconnaître les conséquences prévisibles (notamment les risques et bienfaits potentiels) d'une décision ou de l'absence de décision. Un patient compétent ou son mandataire peut donner ou refuser son consentement éclairé concernant un plan thérapeutique lorsqu'il comprend de façon raisonnable le diagnostic, les risques, les bienfaits et les alternatives indiquées d'un point de vue clinique.

Le mandataire est également appelé décideur par procuration ou représentant. Lorsqu'un patient n'est plus compétent pour prendre des décisions concernant ses soins de santé, il convient d'identifier un mandataire adéquat; ce mandataire devrait disposer des mêmes occasions de discuter en profondeur du plan de soins du patient. Ce représentant devrait être choisi en fonction de sa volonté et de sa capacité à prendre des décisions qui reflètent les volontés les plus récentes du patient, si elles ont été énoncées de façon explicite, ou ses volontés probables, si elles n'ont pas été exprimées. Dans certains cas, un mandataire pourrait avoir déjà été légalement nommé. Il est important de se référer aux lois locales afin de s'assurer de respecter le processus adéquat. ${ }^{2}$

La norme de soins fait suite à la décision de la Cour dans Crits c. Sylvester (1956) S.C.R. 991. Selon cette décision, un médecin « ... doit exercer le degré de soins et d'habileté qui devraient être attendus, de manière raisonnable, d'un praticien prudent ayant la même expérience et réputation... ». Autrement dit, on s'attend à ce qu'un médecin propose ou procure un traitement que la plupart des médecins possédant une formation et une expérience semblables proposerait ou procurerait dans une situation semblable. À l'inverse, cela veut dire qu'on ne s'attend pas à ce qu'un médecin propose ou procure un traitement que la plupart des médecins possédant une formation et une expérience semblables ne proposerait ou ne procurerait pas dans une situation particulière. 


\subsection{Principes éthiques}

Quatre principes éthiques de base, ${ }^{3}$ décrits ci-dessous, sont liés entre eux et se complètent mutuellement. Ces principes ont pour but d'encadrer les discussions; toutefois, ils ne dictent pas ce que les professionnels de la santé «devraient» ou «doivent» faire, que ce soit de façon individuelle ou collective. Il arrive fréquemment que ces principes entrent en conflit - typiquement entre le respect de l'autonomie et le principe de bienfaisance, entre la bienfaisance et la non-malfaisance, ou entre le respect de l'autonomie et la justice. Aucun principe unique n'est supérieur aux autres, et une connaissance approfondie de ces éléments a pour but d'aider à la gestion ou au règlement des dilemmes et des conflits.

La bienfaisance désigne tout acte qui a pour objectif d'être bénéfique aux patients par le traitement de la maladie, la promotion de la santé, et/ou le soulagement de la douleur, de la souffrance et de la détresse.

La non-malfaisance, soit le principe de "primum non nocere » ou " avant tout ne pas nuire », requiert que les professionnels de la santé s'efforcent de minimiser la souffrance, les maux ou la détresse du patient. Un traitement proposé pourrait comporter un mal, une souffrance et une détresse inévitables; dans un tel cas, il doit se justifier par l'attente raisonnable d'un bienfait pour le patient.

Le respect de l'autonomie affirme le droit des patients ou mandataires compétents d'accepter ou de refuser des traitements médicaux. Cela comprend le droit d'accepter ou de refuser tout traitement de maintien de la vie. Le consentement requiert une explication raisonnable de la nature et des implications des interventions proposées et offre une compréhension des conséquences de toute décision d'accepter ou de renoncer à ces interventions. Les patients compétents peuvent conserver leur autonomie dans des états futurs d'incapacité en énonçant leurs objectifs, leurs volontés et leurs préférences de traitement, ou en désignant un mandataire qui représentera ces valeurs suite à une incapacité (voir Section 2.4).

La justice est le principe par lequel tous les patients devraient disposer d'un accès équitable aux soins de santé. Cela comprend les traitements de maintien de la vie, à moins qu'il n'y ait aucune attente raisonnable que ce traitement ait une issue acceptable pour le patient ou qu'il soit déterminé qu'un tel traitement ne servirait qu'à retarder une mort inévitable. Dans certaines situations exceptionnelles, telles qu'une pandémie ou un triage suite à une catastrophe, les ressources médicales (en accord avec les normes de pratique médicale) devraient être allouées afin de maximiser les chances de réussite.

\section{Section 2}

2.1 Distinction entre l'abstention et l'interruption d'un traitement de maintien de la vie au Canada

L'éthique biomédicale occidentale ne fait pas la distinction entre l'abstention de traitement de maintien de la vie et l'interruption d'un traitement de maintien de la vie. Dans certains pays, l'abstention d'un traitement de maintien de la vie peut être permise, mais l'interruption d'un traitement de maintien de la vie est considérée comme contraire à l'éthique ou illégale, indépendamment du consentement. Au Canada, ni l'abstention ni l'interruption des traitements de maintien de la vie ne sont considérées comme la cause de décès; en effet, c'est le processus pathologique qui est responsable de la mort. Toutefois, il peut y avoir une différence psychologique entre l'abstention et l'interruption des traitements de maintien de la vie. Bon nombre de patients, de membres de la famille, et certains professionnels de la santé ne sont pas à l'aise avec la responsabilité morale impliquée dans l'interruption d'un traitement de maintien de la vie (c.-à-d. un geste actif) et acceptent mieux l'abstention de traitement de maintien de la vie (soit un acte passif d'omission).

Il est important de ne pas exagérer la distinction morale ou légale entre l'abstention et l'interruption d'un traitement de maintien de la vie, étant donné qu'il pourrait n'y avoir aucune distinction significative d'un point de vue clinique entre l'interruption d'un traitement ou l'abstention de la prochaine dose ou d'une augmentation de la dose. L'interruption de traitement peut habituellement être reformulée comme une abstention de traitement, et vice versa. Par exemple, la cessation d'une hémodialyse intermittente peut être considérée comme une interruption de l'hémodialyse ou comme une abstention de dialyse supplémentaire. Une ordonnance de ne pas réanimer signifierait l'abstention de toute RCR future. À l'inverse, elle pourrait être formulée comme l'interruption d'un plan de traitement précédent qui incluait la RCR en cas d'arrêt.

Deuxièmement, toute forme de traitement de maintien de la vie devrait être envisagée comme un essai qui devrait se poursuivre aussi longtemps que le patient le souhaite et qu'elle implique une perspective raisonnable de récupération jusqu'à une qualité de vie significative pour le patient. Si le patient retire son consentement à quelque moment que ce soit, ou si l'équipe de soins de santé estime qu'il n'y a pas de perspective réaliste de rétablissement significatif, l'essai devrait alors être interrompu ou modifié.

En termes cliniques pratiques, le fait de faire une distinction entre l'abstention et l'interruption d'un traitement de maintien de la vie pourrait avoir un effet négatif sur les patients. Cela pourrait empêcher l'interruption adéquate de la réanimation une fois qu'il 
est devenu clair qu'elle n'a pas rétabli la vie, et le traitement de maintien de la vie pourrait se voir illimité dans le temps malgré les souffrances du patient ou l'absence de bienfait significatif. En outre, si l'abstention et l'interruption des traitements de maintien de la vie sont jugées distinctes et séparées d'un point de vue moral, alors les patients, les familles ou les médecins pourraient hésiter à amorcer un essai de traitement de maintien de la vie dans les cas dont l'issue est indéterminée. En d'autres mots, lorsqu'il existe une probabilité raisonnable mais non absolue de pronostic néfaste, il pourrait y avoir des réticences à amorcer un essai si l'on ne dispose pas d'option subséquente de l'interrompre.

En résumé, il est essentiel à la pratique médicale que toute intervention médicale, et pas seulement les traitements de maintien de la vie, soit personnalisée selon les bienfaits au patient, réévaluée fréquemment, et qu'il soit possible de l'interrompre. Cette approche minimise les souffrances et la détresse indues des patients et des personnes prenant soin d'eux, l'épuisement professionnel des professionnels de la santé, et l'utilisation inadaptée de ressources limitées.

En Ontario, la Cour suprême du Canada a passé en revue la légalité de l'équivalence entre abstention et interruption de traitement. ${ }^{4}$ La Cour a déterminé que le consentement est requis pour l'interruption d'un traitement de maintien de la vie pour un patient dont la mort imminente est prévisible sans ce traitement de maintien. Toutefois, cette décision non unanime (5-2) est problématique :

i) Elle n'a pas déterminé de façon explicite si l'abstention et l'interruption d'un traitement de maintien de la vie sont équivalentes.

ii) La Cour réfère aux lois provinciales pour résoudre le désaccord entre les professionnels de la santé et la famille/le mandataire quant à l'interruption d'un traitement de maintien de la vie. Les provinces et territoires ne disposent pas tous des lois pertinentes.

iii) La Cour spécifie que la nécessité d'un consentement pour l'interruption d'un traitement de maintien de la vie est spécifique au cas Rasouli (c'est-à-dire l'interruption de la ventilation mécanique chez un blessé crânien grave), et que toutes les formes d'interruption de traitement ne nécessiteraient pas forcément un consentement. Toutefois, la décision n'a pas défini plus en détail les cas dans lesquels un consentement serait nécessaire pour d'autres formes d'interruption de traitement de maintien de la vie.

En outre, certains cas survenus dans d'autres provinces n'ont pas clarifié le rôle du consentement en ce qui touche à l'abstention et à l'interruption des traitements de maintien de la vie. En tant que telle, la légalité au Canada d'une prise de décision d'abstention d'un traitement de maintien de la vie demeure indéterminée, et la légalité de la prise de décision d'interruption de traitement n'est que très étroitement définie en Ontario. ${ }^{5}$

2.2 L'abstention et l'interruption de traitements de maintien de la vie : considérations pour la prise de décision

(i) En se fondant sur leur meilleur jugement clinique, les membres de l'équipe de soins de santé devraient déterminer s'il y a une chance raisonnable que le traitement de maintien de la vie redonne au patient une qualité de vie qu'il trouverait significative. Lorsqu'il est clair que le traitement ne sera pas efficace d'un point de vue médical et qu'il ne respecterait pas la norme de soins, le médecin n'est pas tenu d'amorcer, de continuer ou de maintenir le traitement. (1)

(ii) Les traitements de maintien de la vie ne sont pas un plan de traitement «tout ou rien ». En tant que telle, une ordonnance d'abstention de RCR (ou de ne pas réanimer) ne devrait pas nécessairement signifier que les patients ne peuvent pas recevoir d'autres traitements de maintien de la vie adaptés ou être admis à l'USI. De la même manière, les patients qui refusent ou auxquels on ne propose pas de traitement de maintien de la vie peuvent tout de même recevoir des soins médicaux énergiques, lesquels peuvent comprendre des traitements (par ex., antibiotiques, thérapies interventionnelles, tests radiologiques, examen de laboratoire), des efforts soutenus pour favoriser la réhabilitation (nourriture et hydratation, physiothérapie) et toute l'attention des professionnels de la santé (analgésie, soins spirituels, mises à jour régulières pour le patient et sa famille). Une limite au traitement de maintien de la vie ne devrait pas être interprétée ou représentée comme entraînant l'abandon du patient.

(iii) S'il n'est pas clair si un patient peut retrouver une qualité de vie significative, un essai de traitement de maintien de la vie pourrait être offert tout en étant révisé sur une base régulière afin d'évaluer son bienfondé. L'équipe de l'USI devrait communiquer de façon claire et cohérente avec le patient et son mandataire/les membres de sa famille quant aux buts et objectifs du traitement de maintien de la vie. Il est possible qu'un tel traitement de maintien de la vie soit adapté au début, mais devienne inadapté en raison de changements de l'état du patient. Dans un tel cas, l'équipe de l'USI devrait proposer d'interrompre le traitement de maintien de la vie et de prioriser les soins palliatifs. 
(iv) Il devrait y avoir consensus parmi les membres de l'équipe de l'USI quant aux options (y compris les soins palliatifs) et au plan recommandé avant qu'un membre approche le patient/son mandataire concernant l'abstention et l'interruption de traitements de maintien de la vie. Dans certaines circonstances, il pourrait être préférable de demander au moins une évaluation supplémentaire à un autre médecin de l'USI afin de s'assurer que toutes les options raisonnables ont été envisagées et que l'abstention et l'interruption des traitements de maintien de la vie respectent la norme de soins. L'équipe pourrait également demander une consultation supplémentaire auprès d'autres cliniciens ou éthiciens pertinents afin de déterminer s'il convient d' offrir/de poursuivre les traitements de maintien de la vie.

(v) Il est important que les professionnels de la santé maintiennent une communication cohérente avec le patient/son mandataire. Des structures doivent être en place pour faciliter un transfert complet et régulier entre les professionnels de la santé.

(vi) Lors de l'évaluation d'un problème médical particulier pour déterminer s'il est probablement réversible/récupérable, la justesse/désirabilité d'amorcer ou de poursuivre un traitement de maintien de la vie devrait être interprétée en tenant compte du pronostic global du patient, de ses valeurs et de ses objectifs à plus long terme.

(vii) Lors de la planification de discussions concernant l'abstention et l'interruption de traitements de maintien de la vie, d'autres membres de l'équipe de soins de santé devraient être impliqués. Il pourrait également être adapté, si le patient/son mandataire ou la famille est d'accord, de demander la présence supplémentaire d'un intervenant en soins spirituels adéquat et/ou d'un travailleur social. Il est important de clarifier quels membres de la famille et amis devraient être présents pendant les discussions.

(viii) Une bonne communication est essentielle à la prise de décision. Lorsque cela est possible, le patient, le mandataire et la famille devraient tous prendre part au processus de prise de décision, étant donné que chacun d'entre eux devra faire face aux conséquences et à la détresse potentielle provoquées par la décision. Une bonne communication entre l'équipe de l'USI, le patient/mandataire et la famille peut améliorer la confiance et le soutien mutuels et réduire la possibilité de désaccord ou de confusion. C'est pourquoi les cliniciens et les mandataires devraient s'efforcer de maintenir ouvertes les lignes de communication. (ix) Tous les efforts nécessaires devraient être déployés afin que les patients soient impliqués dans les discussions portant sur leurs propres décisions médicales et leur traitement. Toutefois, en raison de la nature-même d'un collapsus cardiovasculaire, bon nombre de patients seront comateux et incapables de communiquer ou n'y parviendront que partiellement. Lorsque la communication directe avec le patient est possible, la divulgation des informations peut se faire de manière judicieuse afin d'éviter d'imposer une charge émotionnelle importante à une personne peut-être déjà en détresse. Cela pourrait inclure de demander au patient à quel point il souhaite connaître les détails de son état ou de lui fournir des informations limitées de prime abord, en attendant un cadre plus adapté, du soutien supplémentaire, et une meilleure disposition du patient à recevoir ces informations. De cette façon, la confiance peut demeurer intacte et permettre des discussions subséquentes, lorsqu'une divulgation complète pourra avoir lieu.

(x) Certains patients pourraient ne pas vouloir connaître leur état de santé ni être impliqués dans les décisions de traitement. L'équipe de l'USI peut souhaiter recommander que le patient prenne part aux décisions de traitement le concernant; toutefois, elle doit respecter la décision de ce dernier s'il est clair qu'il ne le souhaite pas. Un médecin qui ne tient pas compte de cette préférence ne respecte pas l'autonomie du patient. Une façon pour les médecins de déterminer si leur patient souhaite être impliqué ou non serait de procéder de façon non menaçante et sans jugement en posant la question suivante : «Lorsque je parle aux patients, certains veulent tout savoir sur leur état de santé et les options thérapeutiques. D'autres préfèrent ne rien savoir et veulent que je prenne les décisions de traitement avec leur famille. L'une ou l'autre approche me convient, mais j'aimerais savoir laquelle vous préférez. »

(xi) Il est important de reconnaître l'influence de facteurs non médicaux dans les discussions portant sur l'abstention et l'interruption de traitements de maintien de la vie. Les patients pourraient avoir des convictions culturelles/religieuses/spirituelles qui ont façonné leur attitude envers la vie, la maladie et la mort et qui influenceront leurs émotions concernant l'abstention et l'interruption de traitements de maintien de la vie. Les opinions individuelles des membres de l'équipe de l'USI ne doivent pas interférer avec la prestation de soins non biaisés et exempts de jugement. Il existe de nombreuses confessions et croyances pratiquées au Canada, et les professionnels de la santé ont souvent 
affaire à des patients dont la confession et les croyances diffèrent des leurs. Les services de santé spirituelle sont une ressource précieuse pour explorer et valoriser ces perspectives.

(xii) Étant donné que les familles, les mandataires et les membres de l'équipe de santé pourraient avoir besoin de temps pour accepter la mort imminente d'un patient/d'un être aimé, toute recommandation visant à interrompre ou limiter les soins intensifs devrait faire l'objet de discussions empreintes de respect et de compassion. Les professionnels de la santé peuvent demander conseil au service de consultation éthique, au service de santé spirituelle, aux travailleurs sociaux et/ou à toute autre ressource disponible. En outre, les considérations suivantes s'appliquent :

- Pour faire preuve de bienfaisance et de compassion, le processus décisionnel doit se faire, dans la mesure du possible, sans hâte. Étant donné que les patients/mandataires et les membres de la famille pourraient avoir besoin de temps pour accepter l'abstention et l'interruption de traitements de maintien de la vie proposées, ce processus pourrait nécessiter plus d'une rencontre.

- Les discussions devraient être calmes, honnêtes, respectueuses et empreintes de compassion. Il faut éviter d'employer le jargon médical de sorte que tout le monde comprenne les termes utilisés.

- Tout en étant conscient(e) que le plan médical proposé respecte le meilleur intérêt du patient, la famille/le mandataire pourrait, pour diverses raisons personnelles, psychologiques, ou culturelles, ne pas accepter le fardeau de la prise de décision et ne pas fournir de consentement de façon explicite (ou « donner la permission »). Il est important que l'équipe de l'USI reconnaisse ces situations, dans lesquelles un consentement implicite est préféré.

- Les patients/mandataires et les membres de la famille pourraient percevoir l'abstention et l'interruption de traitements de maintien de la vie comme une forme d'abandon. Il est important de déployer tous les efforts nécessaires pour offrir un soutien et souligner que les soins, y compris la prise en charge des symptômes, seront poursuivis afin de minimiser la détresse du patient. Lorsque cela est indiqué, il convient de souligner le fait que l'abstention et l'interruption du traitement de maintien de la vie sont alors bénéfiques, car ces modalités permettent de se concentrer pleinement sur le confort du patient, ce qui ne serait peut-être pas possible autrement.

(xiii) Il convient de documenter les noms des personnes présentes, le contenu de la discussion, ainsi que le plan et les délais liés à l'abstention et l'interruption des traitements de maintien de la vie. Dans les discussions qui suscitent d'importantes inquiétudes, il est conseillé que les médecins en charge cosignent ou documentent la rencontre eux-mêmes.

(xiv) Lorsque les considérations ci-dessus sont appliquées, les chances de désaccord concernant l'abstention et l'interruption de traitements de maintien de la vie entre l'équipe de l'USI et le patient ou le mandataire sont moindres. Toutefois, lorsqu'il y a désaccord, cela survient souvent dans deux situations distinctes :

1) une discussion concernant un patient dont l'état se dégrade et dont on s'attend à ce qu'il meure bientôt, et 2) une discussion préventive concernant un patient sans attente de détérioration imminente.

Dans la première situation, si une escalade importante des soins (par ex., l'exécution de compressions thoraciques dans le cadre d'une condition en détérioration malgré des traitements continus de maintien de la vie) est considérée comme hors de la norme de soins, alors les patients/mandataires devraient être informés que cette modalité ne sera pas offerte. Dans le cas d'une telle dégradation, il convient également de clarifier que le patient ne sera pas négligé, ignoré ou abandonné, et qu'il recevra des soins complets afin de minimiser son inconfort et de traiter/prévenir les souffrances tels que nécessaires. Ces efforts n'ont pas pour but d'accélérer le processus de décès; plutôt, ils visent à maximiser les bienfaits aux patients et minimiser le mal (voir Section 3.2 pour une discussion approfondie).

Dans le second cas, il est prudent de ne pas hâter les décisions et de souligner que la décision n'affecte que les soins que le patient recevrait si son état venait à se dégrader malgré tous les efforts thérapeutiques raisonnables. L'objectif est d'explorer la situation de façon préventive, de donner du temps pour discuter et revoir les options, et de maximiser la probabilité que le patient communique ses volontés. L'objectif est de minimiser les écueils de communication subséquents et d'atteindre un consensus sans ajouter à la difficulté de prendre une décision en étant pressé par le temps. Le plan devrait refléter les meilleurs intérêts du patient et devrait être respecté par le mandataire/la famille et l'équipe de soins de santé.

Dans les deux cas, le médecin de l'USI devrait envisager d'utiliser toutes les ressources disponibles afin d'éclairer la décision. Cela peut comprendre la confirmation du consensus parmi les autres membres de l'équipe de soins 
de santé et l'obtention d'opinions supplémentaires de collègues, soit en personne ou à distance.

Les établissements/régions de santé devraient mettre en place un processus de communication au sein de l'équipe de soins de santé qui permette de passer en revue régulièrement ces questions, en temps réel et rétrospectivement. Les disputes concernant les objectifs des soins devraient être traitées en faisant appel à d'autres opinions de médecins, particulièrement si le patient est stable et qu'il n'y a pas de contrainte temporelle importante. Ainsi, on augmente la transparence et le respect des normes de pratique. Cela permet également d'éliminer la perception d'une prise de décision unilatérale.

Les professionnels de la santé devraient également être au courant des processus de résolution de conflit locaux (voir 3.4).

(Xv) Il est important de connaître les différences locales et de respecter les politiques applicables de l'Ordre provincial ainsi que les lois provinciales (là où elles existent) qui ont trait à l'abstention et l'interruption des traitements de maintien de la vie. ${ }^{6-9}$

(xvi) Les décisions concernant les traitements de maintien de la vie doivent être révisées en cas de tout changement important ou inattendu à l'état du patient qui pourrait modifier le pronostic précédemment déclaré et sur lequel le plan de soins précédent était fondé.

2.3 L'abstention et l'interruption de traitements de maintien de la vie à la demande d'un patient compétent

(i) Un patient compétent a le droit de renoncer ou de demander une interruption de toute forme d'intervention médicale, y compris d'un traitement de maintien de la vie. Ces décisions doivent être informées, volontaires et sans contrainte, et prises de préférence lorsque la compétence et la capacité du patient à communiquer ne sont pas compromises. Le respect des volontés d'un patient de renoncer à une intervention proposée se distingue de l'aide médicale à mourir (voir Section 2.5).

(ii) Lorsqu'un mandataire/membre de la famille exprime des volontés/opinions contraires à celles exprimées par un patient compétent, ces opinions devraient être notées et discutées, mais elles ne peuvent primer sur les choix exprimés par le patient. Si le patient perd ses capacités par la suite, le mandataire/membre de la famille ne peut substituer ses propres volontés aux volontés connues du patient.

(iii) Si un patient compétent change d'avis concernant ses volontés exprimées, les dernières volontés exprimées prévalent dans le contexte du traitement offert, qu'elles confirment ou contredisent les décisions antérieures.

\subsection{L'abstention et l'interruption de traitements de maintien de la vie par prise de décision de substitution}

La planification des soins avancés est un processus de discussion et de communication préventif qui a pour but que les patients établissent leurs objectifs, leurs valeurs et leurs préférences en matière de soins. Cela comporte la nomination d'un mandataire et, souvent, de la documentation écrite. Cette documentation peut prendre la forme de directives, de testaments biologiques, ou de plans de soins. L'intention de cet exposé de principe n'est pas l'élaboration plus détaillée de ce processus; toutefois, les informations ci-dessous peuvent servir de guide :

\subsubsection{Directives}

(i) Une directive est un document exécuté par une personne compétente concernant des décisions de soins de santé qui devront être prises au cas où cette personne deviendrait inapte à prendre de telles décisions. L'objectif d'une directive est de maintenir l'autonomie du patient même lorsqu'il perd sa capacité décisionnelle. La directive s'adresse au mandataire/à la famille et à l'équipe de soins de santé. Une copie de la directive devrait accompagner le patient lors de son admission dans un établissement de soins de santé.

En règle générale, une directive spécifie un mandataire individuel que le patient a désigné pour prendre des décisions de soins de santé au cas où il perdrait sa capacité décisionnelle. Elle peut également spécifier les valeurs du patient, des instructions à suivre afin d'informer les décisions en matière de soins de santé ou indiquer des traitements spécifiques que le patient aimerait recevoir ou non. Une directive ne peut pas obliger l'équipe de soins de santé à procurer des traitements qui sont hors de la norme de soins, et elle ne peut ordonner à un intermédiaire de le faire. Les énoncés catégoriques (par ex., « Je ne veux jamais recevoir...» ou «Je désire une RCR peu importe ce qu'il arrive ») doivent être pris en considération mais ne devraient pas être interprétés en tant qu'instructions littérales lorsqu'ils sont émis en l'absence de tout contexte clinique.

De nombreux types de directives différents, par exemple génériques, spécifiques à une maladie, ou institutionnelles, sont utilisés au Canada. Les lois 
provinciales et les politiques institutionnelles varient également, et les professionnels de la santé doivent connaître leurs exigences locales. ${ }^{2}$

(ii) Lorsqu'il n'y a pas de directive écrite, un patient compétent et informé peut communiquer ses volontés et préférences verbalement, et ces directives orales devraient guider les soins dans la même mesure que des instructions écrites. Cependant, cette conversation devrait être documentée selon la politique institutionnelle, de telle manière à ce qu'elle informe les rencontres futures portant sur ses soins de santé.

En règle générale, les énoncés d'un patient en incapacité aiguë (un état en relation avec une maladie en phase aiguë ou des médicaments et par conséquent réversible) ne remplacent pas les énoncés/directives antérieurs du patient alors qu'il était compétent. Toutefois, en cas de divergences, les médecins doivent tenir compte du contexte clinique et des meilleurs intérêts présumés du patient. Les nouvelles informations qui n'étaient pas disponibles au patient lorsqu'il a établi ses directives pourraient avoir une influence et justifier une révision des objectifs actuels et futurs.

\subsubsection{Absence de directive}

(i) Dans les situations d'urgence, telles qu'un arrêt cardiaque, des décisions médicales pourraient devoir être prises avant d'avoir eu connaissance ou de passer en revue une directive. Dans cette situation, les professionnels de la santé et les mandataires devraient se conformer à ce qu'ils pensent être dans le meilleur intérêt du patient.

(ii) Lorsque cela est possible, un mandataire devrait être identifié conformément aux lois provinciales adéquates et aux politiques institutionnelles, et cette personne devrait participer au processus de prise de décision au nom du patient.

(iii) Le mandataire identifié est la source reconnue de consentement aux plans de traitement. Le rôle d'un mandataire est de reproduire les choix qu'un patient ferait s'il en avait encore la capacité. Dans cette situation, la perception de bien-être du patient est respectée, tout comme son intérêt d'autodétermination. En l'absence de directives claires et pertinentes, le mandataire devrait appliquer la norme du «meilleur intérêt». Cette norme comprend la prise en compte du bien-être global du patient, ses valeurs et croyances générales, et les fardeaux et bienfaits potentiels des options thérapeutiques. (iv) Si l'on soupçonne que le mandataire n'agit pas dans le meilleur intérêt du patient, l'équipe de l'USI devrait alors explorer les raisons sous-jacentes aux décisions du mandataire. Il pourrait être nécessaire de faire appel à des ressources locales, y compris aux relations du patient, au service de consultation en éthique, ou à un avocat-conseil, afin de clarifier le rôle du mandataire et les meilleurs intérêts du patient. Dans certaines juridictions, l'équipe de l'USI peut faire appel à des entités légales ou à un tribunal, tel que la Commission du consentement et de la capacité (en Ontario et au Yukon), pour obtenir des conseils ou pour permettre à l'équipe de s'en référer à un autre mandataire.

\subsection{Mourir dans le respect et la dignité}

(i) Si des décisions sont prises à l'effet de ne pas offrir ou d'interrompre un traitement de maintien de la vie, les objectifs des soins au patient à l'USI se concentreront sur le confort et le soulagement des souffrances. L'équipe de l'USI devrait offrir un environnement respectueux, attentionné et paisible afin de garantir une mort dans la dignité et une expérience familiale respectueuse.

(ii) Les services de consultation en soins palliatifs peuvent proposer une expertise et un soutien supplémentaires, et leur utilisation a été associée à une survie prolongée des patients. ${ }^{10}$ En tant que tels, les soins palliatifs devraient être envisagés dans la transition vers des soins de confort.

(iii) Il faut être conscient que tous les patients ne vont pas mourir de façon imminente lorsqu' on n'offre pas ou qu'on interrompt des traitements de maintien de la vie. En fait, certains survivront et seront transférés hors de l'USI. Les professionnels de la santé devraient préparer la famille à cette éventualité et s'assurer que le temps qu'il reste au patient soit aussi confortable que possible.

(iv) La bienfaisance et la compassion requièrent de l'équipe de l'USI qu'elle soutienne et facilite les préparatifs pour le patient et la famille en cas de mort imminente du patient. Cela pourrait comprendre d'envisager, de façon raisonnable, une prolongation limitée des efforts de maintien de la vie jusqu'à ce que certains objectifs sociaux et spirituels soient remplis.

(v) Lors de l'abstention ou de l'interruption d'un traitement de maintien de la vie, l'équipe de l'USI pourrait utiliser des opiacés et/ou d'autres sédatifs pour soulager les souffrances. Bien que les sédatifs et les opioïdes ne précipitent en général pas le décès 
lorsqu'ils sont dosés de façon à procurer du confort, il est possible que ces médicaments précipitent involontairement la mort du patient. Selon la doctrine du double effet, il est acceptable que des médicaments de confort précipitent potentiellement la mort, tant que ce n'est pas l'effet intentionnel lorsqu'on administre ces médicaments. ${ }^{11}$ Cela diffère de l'euthanasie et du suicide assisté, dans lesquels des médicaments sont administrés aux fins délibérées de précipiter la mort.

Bien que l'aide médicale à mourir (AMM) soit décriminalisée au Canada lorsqu'elle respecte certaines circonstances spécifiques, ${ }^{12}$ elle est distincte de l'abstention et l'interruption de traitements de maintien de la vie. Certains patients/mandataires et membres de la famille pourraient juger que l'interruption d'un traitement de maintien de la vie est équivalente à une euthanasie et par conséquent s'y opposer. L'équipe de l'USI devrait expliquer la différence. Dans les cas d'abstention et d'interruption de traitements de maintien de la vie, l'intention de l'équipe de l'USI est de permettre au patient de mourir d'une mort naturelle causée par la maladie sous-jacente ou ses complications, et de procurer le confort nécessaire. En revanche, en cas d'aide médicale à mourir, l'intention est de procurer un confort en terminant délibérément et activement la vie d'un patient. En outre, il est également important de souligner que les conditions et processus spécifiques à l'AMM, bien que possibles, sont rares dans le cadre de l'USI.

\section{Section 3}

\subsection{Considérations multiculturelles}

Les patients, les mandataires et les professionnels de la santé sont le reflet de la composition multiculturelle, multiconfessionnelle et multiethnique du Canada. En raison de la diversité tant au sein et entre les différentes confessions pratiquées au Canada, les membres de l'équipe de l'USI pourraient se retrouver dans des situations où les croyances de leurs patients et familles ne s'alignent pas avec les changements proposés au traitement de maintien de la vie. L'équipe de l'USI doit alors être sensible aux attitudes diverses face à l'abstention et l'interruption de traitements de maintien de la vie. En outre, il peut y avoir des divergences entre les pratiques individuelles et les interprétations courantes des enseignements religieux, divergences qui pourraient susciter des discussions plus poussées. Ainsi, il convient d'être au courant des croyances des patients et de leurs familles dès que l'abstention ou l'interruption d'un traitement de maintien de la vie est envisagée. Dans ces circonstances, une implication précoce du service de santé spirituelle pertinent est recommandée. La Section 2 de la Charte canadienne des droits et libertés protège les Canadiens dans la pratique de la religion de leur choix et contre toute discrimination fondée sur ce choix. Ceci étant dit, il ne faut pas extrapoler ces droits, qui ne protègent pas les demandes qui ne correspondent pas aux normes médicales et laïques.

\subsection{Les ordonnances de réanimation cardiorespiratoire (RCR) et de ne pas réanimer}

Les décisions les plus fréquentes en ce qui touche à l'abstention et l'interruption de traitements de maintien de la vie concernent la restriction ou les limites imposées à la RCR. Il est important de noter que des désaccords entre l'équipe de soins de santé et le patient/son mandataire/sa famille concernant la RCR sont en règle générale liés à une mauvaise information/compréhension du terme « réanimation ». En outre, le désaccord provient en général d'une inquiétude quant au fait qu'une ordonnance de non RCR ou de ne pas réanimer entraînerait une négligence ou une attention très limitée à des conditions autrement traitables et sans rapport avec l'arrêt cardiaque. Il convient par conséquent de fournir une explication appropriée concernant la pertinence d'une ordonnance de ne pas réanimer; cette explication devrait être complétée de la mention spécifique de tous les traitements de maintien de la vie qui seront maintenus, le cas échéant. Il faut être conscient que de nombreuses personnes issues du public (et certains professionnels de la santé) sont mal informées concernant la RCR et ses séquelles, et il convient d'y remédier. ${ }^{13}$ La réanimation cardiorespiratoire se distingue des interventions standard en soins intensifs telles que l'intubation non urgente et la ventilation mécanique, le soutien de l'hémodynamie, ou l'obtention d'accès vasculaire. En outre, les professionnels de la santé devraient expliquer que la probabilité de restaurer la santé cérébrale ou corporelle après une RCR varie mais est souvent basse, particulièrement chez les patients fragiles, ceux dont l'état ne s'est pas amélioré malgré une longue hospitalisation, et ceux souffrant de maladie médicale à un stade avancé. $^{14,15}$

Il n'existe pas de précédent légal au Canada concernant l'exigence de fournir une RCR dans une situation dans laquelle un médecin détermine qu'une telle intervention se situe hors de la norme de soins. La SCSI affirme le principe qu'une RCR ne devrait pas être amorcée en dehors de la norme de soins, comme dans le scénario décrit dans la section 2.2 (xiv). Pour cette raison, la SCSI est en désaccord avec cet aspect de la politique de l'Ordre des médecins et chirurgiens de l'Ontario sur la Planification et l'offre de soins de fin de vie de qualité. L'énoncé de 
l'Ordre des médecins et chirurgiens du Manitoba sur l'abstention et l'interruption de traitements de maintien de la vie mentionne également l'application de la RCR. Dans ces provinces, les praticiens doivent connaître ces politiques. En fin de compte, la durée et les interventions réalisées pendant une RCR devraient s'aligner avec la norme de soins et le jugement clinique, en tenant compte de l'effet potentiel de cette intervention énergique : peutelle renverser une mort prématurée, ou au contraire prolonger le délai avant une mort inévitable ou ajouter des souffrances inutiles pour le patient? Lorsqu'elle est prodiguée, il n'y a aucune durée minimale de la RCR; en outre, aucune intervention n'est obligatoire pendant un épisode de RCR. ${ }^{16,17}$

\subsection{Ressources}

Lorsque les exigences placées sur l'USI excèdent les ressources locales, l'équipe de l'USI se retrouve au centre d'une situation de gestion de crise. Ainsi, il se pourrait que l'équipe traitante soit alors en charge de l'affectation des ressources. Un manque perçu de ressources ne devrait jamais - hormis lorsque les lois entourant une pandémie ou une catastrophe naturelle en décident autrement influencer exclusivement une décision d'abstention ou d'interruption des traitements de maintien de la vie concernant un patient. Des politiques de santé préventives et des mécanismes locaux à divers niveaux (au niveau de l'USI, de l'hôpital, de la région, de la province) doivent régir la prestation de soins à l'USI lorsque nécessaire. La responsabilité d'informer les parties prenantes des exigences et ressources nécessaires à la prestation de soins intensifs adéquats, adaptés et opportuns incombe à la communauté de l'USI.

\subsection{Impasse}

Dans toute situation clinique, il y a au moins deux parties autonomes : le patient/mandataire et le(s) professionnel(s) de la santé. Chacune possède ses responsabilités, ses valeurs et ses systèmes de croyance propres. Le respect mutuel de l'autonomie de chacune de ces parties est essentiel. Toutefois, lorsque l'équipe de soins de santé détermine que certaines interventions spécifiques n'ont pas de bienfait médical et/ou se situent hors des normes de pratiques acceptées, le respect de l'autonomie du patient ne devrait pas forcer l'équipe à acquiescer à la requête du patient/mandataire concernant une intervention. ${ }^{1}$

D'autres sociétés de soins intensifs ont abordé ces questions et offrent des conseils et une réflexion supplémentaires à ce sujet. $^{18,19}$

L'équipe de soins de santé devrait communiquer ces décisions le plus tôt possible et donner aux patients/mandataires l'occasion de ne pas être d'accord ou de demander une ou plusieurs autres opinions. L'équipe devrait tenter de communiquer en toute bonne foi et de trouver un terrain d'entente avec le patient/mandataire concernant le plan de soins. Cependant, il existe toujours certaines situations où le consensus ne peut être atteint et ce, malgré une communication adaptée et une évaluation médicale répétée. Dans de tels cas, d'autres tentatives de règlement doivent être explorées s'il n'y a pas de contrainte importante de temps. Parmi les efforts à déployer, citons :

(i) D'autres efforts de discussion approfondie avec le patient, la famille, d'autres professionnels de la santé et des intervenants en soins spirituels (comme décrit dans la Section 2.2);

(ii) Une rencontre de toutes les parties avec un médiateur ou une tierce partie impartiale, telle qu'un consultant en éthique institutionnelle ou équivalent;

(iii) Un processus formel de résolution de conflit (dans les institutions/régions) qui comprend plusieurs représentants et parties prenantes et qui peut être mis sur pied lorsque la prise de décision est requise tant dans les situations urgentes que dans des situations plus prolongées (Déclaration conjointe sur la prévention et le règlement des conflits éthiques de l'Association médicale canadienne, 1999) ${ }^{20}$;

(iv) L'étude d'un possible transfert du patient à un autre médecin ou une autre institution et, si ce n'est pas faisable, l'explication claire de la situation au patient/mandataire/famille; et

(v) Le jugement par la Commission du consentement et de la capacité, là où elle existe, ou par les tribunaux. Ces options devraient être disponibles pour toutes les parties prenantes; toutefois, il convient de garder à l'esprit que de tels processus ne sont pas sensibles au temps et nécessitent d'importantes ressources. ${ }^{20}$

\section{Conclusion}

Les discussions entourant l'abstention et l'interruption des traitements de maintien de la vie doivent être collaboratives et transparentes. Elles devraient être centrées sur des volontés du patient qui sont informées et liées au contexte et sur des décisions médicales appuyées par un consensus fondé sur des normes. Lorsque les traitements de maintien de la vie ne sont plus bénéfiques ou voulus, une approche d'empathie et de soutien des patients et de leurs familles garantira que les communications soient partagées sous la meilleure lumière possible malgré la difficulté de la situation.

Acknowledgements The authors are grateful for the guidance provided by the original Canadian Critical Care Society position 
paper authored by Dr. Graeme Rocker and Dr. Scott Dunbar. ${ }^{21}$ The authors thank the Canadian Critical Care Society Executive and Board for their review and support with special thanks to Dr. Peter Brindley for his suggested edits.

Conflicts of interest None declared.

Editorial responsibility This submission was handled by Dr. Hilary P. Grocott, Editor-in-Chief, Canadian Journal of Anesthesia.

Author contributions Natalie Bandrauk, James Downar, and Bojan Paunovic contributed substantially to all aspects of this manuscript, including conception and design; acquisition, analysis, and interpretation of data and drafting the article.

Remerciements Les auteurs sont reconnaissants aux auteurs de l'Exposé de principe original de la Société canadienne de soins intensifs, les Drs Graeme Rocker et Scott Dunbar, pour l'inspiration bienvenue de ce texte. ${ }^{21}$ Les auteurs remercient le Conseil d'administration et le Conseil de direction de la Société canadienne des soins intensifs pour leurs révisions et leur soutien, et remercient particulièrement le Dr Peter Brindley pour ses suggestions de corrections.

\section{Conflit d'intérêt Aucun.}

Responsabilité éditoriale Cet article a été traité par Dr Hilary P. Grocott, rédacteur en chef, Journal canadien d'anesthésie.

Contributions des auteurs Natalie Bandrauk, James Downar et Bojan Paunovic ont considérablement contribué à tous les aspects de ce manuscrit, notamment à sa conception et à sa mise au point; à l'acquisition, l'analyse et l'interprétation des données et à la rédaction de l'article.

\section{References}

1. Canadian Medical Association. CMA Policy. CMA Statement on Life Saving and Sustaining Interventions. December 2013. Available from URL: http://policybase.cma.ca/dbtw-wpd/ Policypdf/PD14-01.pdf (accessed September 2017).

2. Speak Up. Advance Care Planning. Available from URL: http:// www.advancecareplanning.ca/ /resource-library/\#resource-librarylcategory:your-province-or-territory (accessed September 2017).

3. Beauchamp TL, Childress JF. Principles of Biomedical Ethics. 6th ed. NY: Oxford University Press; 2009.

4. Supreme Court of Canada. Cuthbertson v. Rasouli, 2013 SCC 53 [2013] 3 S.C.R. Available from URL: https://beta.canlii.org/fr/ca/ csc/doc/2013/2013csc53/2013csc53.pdf (accessed September 2017).

5. Downar J, Sibbald RW, Bailey TM, Kavanagh BP. Withholding and withdrawing treatment in Canada: implications of the Supreme Court of Canada's decision in the Rasouli case. CMAJ 2014; 186: E622-6.

6. Yukon Government. Capability and Consent Board. Available from URL: http://www.yukoncapabilityandconsentboard.ca/ accessed September 2017).

7. Government of Ontario. Consent and Capacity Board. Available from URL: http://www.ccboard.on.ca/scripts/english/index.asp (accessed September 2017).
8. College of Physicians and Surgeons of Ontario. CPSO Statement \#6-16: Planning for and providing quality End of Life Care. 2015. Available from URL: http://www.cpso.on.ca/policiespublications/policy/planning-for-providing-quality-end-of-lifecare\#policy5-2 (accessed September 2017).

9. College of Physicians and Surgeons of Manitoba. CPSM BYLAW 11. Standards of Practice of Medicine, Schedule D: Withholding and Withdrawing Life Sustaining Treatment. 2015. Available from URL: http://cpsm.mb.ca/cjj39alckF30a/wpcontent/uploads/ByLaws/By-Law-11.pdf (accessed September 2017).

10. Temel JS, Greer JA, Muzikansky A, et al. Early palliative care for patients with metastatic non-small-cell lung cancer. N Engl J Med 2010; 363: 733-42.

11. The Special Senate Committee on Euthanasia and Assisted Suicide. Of Life and Death - June 1995, Canada.

12. Government of Canada. An Act to amend the Criminal Code and to make related amendments to other Acts (medical assistance in dying) (S.C. 2016, c. 3). Available from URL: http://laws-lois. justice.gc.ca/eng/AnnualStatutes/2016_3/FullText.html (accessed September 2017).

13. Heyland DK, Frank C, Groll D, et al. Understanding cardiopulmonary resuscitation decision making: perspectives of seriously ill hospitalized patients and family members. Chest 2006; 130: 419-28.

14. Kutsogiannis DJ, Bagshaw SM, Laing B, Brindley PG. Predictors of survival after cardiac or respiratory arrest in critical care units. CMAJ 2011; 183: 1589-95.

15. Brindley $P G$, Markland DM, Mayers I, Kutsoigiannis DJ. Predictors of survival following in-hospital adult cardiopulmonary resuscitation. CMAJ 2002; 167: 343-8.

16. Downar J, Warner M, Sibbald R. Mandate to obtain consent for withholding nonbeneficial cardiopulmonary resuscitation is misguided. CMAJ 2016; 188: 245-6.

17. Oczkowski SJ, Rochwerg B, Sawchuk C. Withdrawing versus not offering cardiopulmonary resuscitation: is there a difference? Can Respir J 2015; 22: 20-2.

18. Bosslet GT, Pope TM, Rubenfeld GD, et al. American Thoracic Society ad hoc Committee on Futile and Potentially Inappropriate Treatment; American Thoracic Society; American Association for Critical Care Nurses; American College of Chest Physicians; European Society for Intensive Care medicine; Society of Critical Care. An Official ATS/AACN/ACCP/ ESICM/SCCM policy statement: Responding to Requests for Potentially Inappropriate Treatments in Intensive Care Units. Am J Respir Crit Care Med 2015; 191: 1318-30.

19. Kon AA, Shepard EK, Sederstrom NO, et al. Defining futile and potentially inappropriate interventions: a policy statement from the Society of Critical Care Medicine Ethics Committee. Crit Care Med 2016; 44: 1769-74.

20. Board of Directors of the Canadian Healthcare Association; Canadian Medical Association; Canadian Nurses Association; Catholic Health Association of Canada. Joint Statement on Preventing and Resolving Ethical Conflicts Involving Health Care Providers and Persons Receiving Care. Available from URL: https://www.cma.ca/Assets/assets-library/document/en/ advocacy/policy-research/CMA_Policy_Preventing_and_resolving ethical_conflicts_involving_health_care_providers_and_persons_ receiving\%20care_PD99-03-e.pdf (accessed September 2017).

21. Rocker G, Dunbar $S$. Withholding or withdrawal of life support: the Canadian Critical Care Society position paper. J Palliat Care 2000; 16(Suppl): S53-62. 